\title{
APPLICATION OF SIMULATION METHODS OF STOCHASTIC PROCESSES TO VORTEX EXCITATION
}

\author{
T. LIPECKI ${ }^{1}$, A. FLAGA ${ }^{2}$
}

\begin{abstract}
A description of direct simulation of crosswind loads caused by critical vortex excitation and the response of the structure to these loads are presented in this paper. Tower-like structures of circular cross-sections are considered. A proposed mathematical model of vortex excitation has been numerically implemented and a selfserving computer program was created for the purpose. This software, cooperating with the FEM system, allows for a simulation of a crosswind load and lateral response in real time, meaning that at each time step of the calculations the load is generated using information regarding displacements seen beforehand. A detailed description of the mathematical model is neglected in this paper, which is focused on numerical simulations. WAWS and AR methods are used in simulations.
\end{abstract}

Keywords: vortex excitation, WAWS, AR, simulation of stochastic processes, circular cross-section

\section{INTRODUCTION}

Free-standing industrial chimneys (steel and concrete) and free-standing towers of circular crosssections constitute a large group of engineering structures. For these kinds of structures, vortex excitation is an important aerodynamic phenomenon. The stochastic character of wind and crosswind vibrations of the structure change both the magnitude and range of vortex excitation, thereby making the problem quite complicated.

\footnotetext{
${ }^{1}$ PhD., Eng., Lublin University of Technology, Faculty of Civil Engineering and Architecture, Nadbystrzycka 40, 20-618 Lublin, Poland, e-mail: t.lipecki@pollub.pl

2 Prof. DSc., PhD., Eng., Cracow University of Technology, Faculty of Civil Engineering, Warszawska 24, 31-155 Cracow, Poland, e-mail: liwpk@windlab.pl
} 
A semi-empirical mathematical model was created in order to describe the crosswind load caused by vortex excitation of circular cylinders. This model can be used both for steady and unsteady wind flows. Moreover, lateral vibrations of structures are considered. All equations derived for the sectional model of the structure were extrapolated to the real structure of the constant or changing along the height circular cross-section. Changes in cross-sections along the height of the structure can be weak, as for tapered chimneys, or strong, as for towers.

The model depends on five experimental parameters which should be taken from full-scale measurements, wind tunnel tests, or on the basis of known literature. Vortex excitation is limited to a short (as opposed to the whole height) part of the structure. A description of the vortex shedding domain is given by the function $Y(z)$ which takes into account several physical aspects of the flow around the circular cylinder. Function $Y(z)$ determines the domain $\Delta L$, where vortex excitation can appear, and its characteristic point $z_{0}$ (centre of domain $\Delta L$ ). The crosswind load caused by vortex shedding is simulated as a stochastic process in point $z_{0}$. It is assumed that the load generated in $z_{0}$ is fully correlated in domain $\Delta L$ and can be applied to the structure in this domain.

A suitable computer program was created to numerically implement the mathematical model. The program allows for a simulation of the crosswind load caused by vortex shedding and lateral response of the structure in real-time. At each time step of calculations the magnitude and the range of the load are determined on the basis of lateral displacements in point $z_{0}$ taken from the time range "before". Our software is based on the Finite Element Method (FEM) system used for calculations of time histories of displacements. Direct integration is used to compute displacements at each time step.

One of the main features of the proposed approach is a method of simulation of vortex excitation. Two stochastic processes simulation methods are used in the experimental considerations: WAWS (weighted amplitude wave superposition) and AR (auto-regressive).

Bases of the WAWS method (also known as the Shinozuka-Jan algorithm) were presented in $[1,2]$, later modifications were elaborated in [3-7]. In general, for wind engineering purposes, WAWS and its combinations are used more frequently to simulate a wind speed field than the family of autoregressive methods. There are several recent applications of both methods in wind engineering.

WAWS was used in the algorithm for fast simulation of wind pressure fields and was presented via an example of the cable-membrane roof of the Foshan Century Lotus Stadium which outer and internal diameters were equal to $310 \mathrm{~m}$ and $125 \mathrm{~m}$, respectively. Two hundred points on the roof structure were chosen for the simulation [11]. A procedure was developed in [12]. According to recent experiments, the wind pressure on the roof structures is of the non-Gaussian feature type. 
A simulation of wind speed in large domains, possibly in zones characterised by complex topography, was presented in [13]. WAWS with several modifications was used for the modelling of the three-dimensional wind turbulence in the case of the non-uniform mean flow via the example of the preliminary-designed Messina Strait bridge; total length of the main span equalling $3300 \mathrm{~m}$ and pylons of height equalling $383 \mathrm{~m}$. Paper [14] tried to define the probabilistic assessment of risk under wind action via the example of the Messina Strait bridge. Earlier, wind speed fluctuations caused by atmospheric turbulence characterized by frequencies below $0.2 \mathrm{~Hz}$ were simulated around the Messina Strait bridge in [15]. Authors focused on the aeroelastic flutter instability of the bridge deck.

WAWS was also used for a simulation of the wind field acting on six different transmission towerline systems. Time-dependent wind speed was generated in 12 points across the towers and in several points (every $10 \mathrm{~m}$ ) on the windward line [16].

The wind-vehicle-bridge coupled vibration analysis based on the random simulation of traffic and wind action was presented in [17]. Wind action was generated through the use of WAWS in several nodes of the cable-stayed Hangzhou Bay Bridge, total length $908 \mathrm{~m}$.

Vibrations of an anchor cable of a 200-meter tall television tower were analyzed in [18]. A stochastic wind field was simulated with WAWS.

Paper [19] described a practical simplified method (based on WAWS) for the simulation of stochastic wind velocity fields for long cable-stayed bridges. The bridge over Yangtze River supporting the high-speed railway in China was considered here; it consists of three pylons of $170 \mathrm{~m}$ and two main spans of $488 \mathrm{~m}$.

Paper [20] performed numerical simulations using WAWS to investigate the total axial fatigue damage of several suspended cables with different initial sags and under different wind excitations. The spectral approach defined by the WAWS method was used to simulate wind velocity time series in order to predict the dynamic responses of slender structures to buffeting forces [21]. The proposed procedure was examined on the example of a typical box girder bridge.

Aerodynamic analyses of the cable-stayed Rędziński Bridge and of two long footbridges in Krakow (based on the three-dimensional WAWS simulation of the wind speed in several points of the structures) were presented in $[22,23,24]$.

AR is a method of simulation using linear filters; its idea is based on the introduction of an initial sequence of random values with normal distribution to the linear filter. The filter is designed to give out the put process of the determined spectrum at the exit. Further time steps of the process are simulated on the basis of the time steps referred to as "backwards", which are taken with 
appropriate multipliers (the so-called auto-regression coefficients). AR and its development to MR (multi-regressive) were described in detail in several papers [3-5, 25-26].

Some recent applications of the family of auto-regressive models contain the buffeting response of the long-span bridge in a time domain [27]. Time histories of wind turbulence were numerically generated by ARMA (auto-regressive moving average, yet another developed AR method) as the input for the approach. The study was performed for the Akashi Kaikyo bridge which main span equals $1990 \mathrm{~m}$.

The use of the ARMA model to simulate the turbulent component of a wind field in a typical downburst was described in $[28,29]$. In the first paper, the authors compared the results to CFD simulations.

Dynamic characteristics of the three-dimensional fluid-structure system, which was aqueduct-water system, were studied in [30]. Fluctuating wind acting on the aqueduct was simulated with ARMA.

There are also some papers which consider and compare two or more methods of simulation. For example, the proposition of the increase in the efficiency of the simulation of the stochastic wind velocity field through the use of WAWS and AR was proposed in [8].

An extensive literature review on numerical simulations of the wind load was carried out in [9], where recent developments and future challenges concerning this field were summarized. WAWS and the family of auto-regressive methods like AR, MA (moving average), and ARMA were described, among others.

Stochastic wind field simulation through the use of WAWS, AR, and POD (proper orthogonal decomposition) methods from the point of view of efficiency, computer effort, and computer memory requirements were compared in [10]. Two case studies were considered: the pylon and the entirety of the suspension bridge.

It should be emphasized that both methods are often used in wind engineering to simulate wind velocity fields, but here they are used directly to simulate vortex shedding. Further considerations show that WAWS can be used for vortex shedding generation, while AR cannot.

\section{Methods OF SIMULATION}

\subsection{WAWS - Weighted AMPLITUdE WAVE SUPERPOSITION}

Below is a general description of the method that allows us to simulate the process in many points in three dimensions, and its simplification to the variant which allows us to simulate a fully 
correlated vortex excitation process in domain $\Delta L$ at point $z_{0}$. Simulations according to WAWS are based on the knowledge of the power spectral density function (PSD) of the analysed process.

The family of $M$ correlated stochastic processes (in any $M$ points) can be generated according to the following system of equations:

$$
p_{i}(t)=\sum_{k=1}^{N} \sum_{j=1}^{i} H_{i j}\left(f_{k}\right) \cos \left(2 \pi\left(f_{k}+\delta f_{k}\right)\left(t+t_{i j}\right)+\Phi_{k}\right)
$$

Assuming, that $t_{i j}=0$ (flow time shift between two points) and moreover that $f_{k}+\delta f_{k}=f_{k}^{\prime}$, system of equations Eq. (2.1) can be rewritten:

$$
p_{i}(t)=\sum_{k=1}^{N} \sum_{j=1}^{i} H_{i j}\left(f_{k}\right) \cos \left(2 \pi f_{k}^{\prime} t+\Phi_{k}\right)
$$

The following denotations are introduced in Eqs. (2.1) and (2.2): $N$ - number of spectrum intervals, $t$ - time, $p_{i}(t)-M$ correlated stochastic processes:

$$
p_{i}(t)=\left[\begin{array}{c}
p_{1}(t) \\
p_{2}(t) \\
\vdots \\
p_{M}(t)
\end{array}\right]
$$

$f_{k}(k=1,2 \ldots . N)$ - central frequency of frequency interval $\Delta f$ (Fig. 1), $H_{i j}\left(f_{k}\right)(k=1,2 \ldots N)$ - set of $N$ lower-triangle matrixes of dimensions $M \mathrm{x} M$, which are determined on the basis of PSD functions of the processes, $f^{\prime}{ }_{k}-$ set of $N$ frequencies:

$$
f_{k}^{\prime}=\left[\begin{array}{c}
f_{1}+\delta f_{1} \\
f_{2}+\delta f_{2} \\
\vdots \\
f_{N}+\delta f_{N}
\end{array}\right]
$$

where: $k$-th element is the sum of central frequency $f_{k}$ in interval $\Delta f$ (Fig. 1) and random shift (disturbance) $-\delta f_{k}$ : 


$$
f_{k}^{\prime}=f_{k}+\delta f_{k}
$$

moreover, value $\delta f_{k}$ should be much lower than $\Delta f / 2, \Phi_{k}$ - set of $N$ random values of phase shift angles taken from a range of $0,2 \pi$ :

$$
\Phi_{k}=\left[\begin{array}{c}
\Phi_{1} \\
\Phi_{2} \\
\vdots \\
\Phi_{N}
\end{array}\right]
$$

Expressions $H_{i j}\left(f_{k}\right)$ can be put together in the lower-triangle matrix

$$
\mathbf{H}\left(f_{k}\right)=\left[\begin{array}{cccc}
H_{11}\left(f_{k}\right) & 0 & \cdots & 0 \\
H_{21}\left(f_{k}\right) & H_{22}\left(f_{k}\right) & \cdots & 0 \\
\vdots & \vdots & \ddots & \vdots \\
H_{M 1}\left(f_{k}\right) & H_{M 2}\left(f_{k}\right) & \cdots & H_{M M}\left(f_{k}\right)
\end{array}\right]
$$

thereby the system of equations Eq. (2.2) takes the following form:

$$
\left[\begin{array}{c}
p_{1}(t) \\
p_{2}(t) \\
\vdots \\
p_{M}(t)
\end{array}\right]=\sum_{k=1}^{N}\left[\begin{array}{cccc}
H_{11}\left(f_{k}\right) & 0 & \cdots & 0 \\
H_{21}\left(f_{k}\right) & H_{22}\left(f_{k}\right) & \cdots & 0 \\
\vdots & \vdots & \ddots & \vdots \\
H_{M 1}\left(f_{k}\right) & H_{M 2}\left(f_{k}\right) & \cdots & H_{M M}\left(f_{k}\right)
\end{array}\right] \cdot\left[\begin{array}{c}
\cos \left(2 \pi f_{k}^{\prime}+\Phi_{k}\right) \\
\cos \left(2 \pi f_{k}^{\prime}+\Phi_{k}\right) \\
\vdots \\
\cos \left(2 \pi f_{k}^{\prime}+\Phi_{k}\right)
\end{array}\right]
$$

Exemplary first two equations of the system take the form:

$$
p_{1}(t)=H_{11}\left(f_{1}\right) \cos \left(2 \pi\left(f_{1}+\delta f_{1}\right)+\Phi_{1}\right)+H_{11}\left(f_{2}\right) \cos \left(2 \pi\left(f_{2}+\delta f_{2}\right)+\Phi_{2}\right)+\ldots
$$

$$
\begin{gathered}
\ldots+H_{11}\left(f_{N}\right) \cos \left(2 \pi\left(f_{N}+\delta f_{N}\right)+\Phi_{N}\right) \\
p_{2}(t)=H_{21}\left(f_{1}\right) \cos \left(2 \pi\left(f_{1}+\delta f_{1}\right)+\Phi_{1}\right)+\ldots+H_{21}\left(f_{N}\right) \cos \left(2 \pi\left(f_{N}+\delta f_{N}\right)+\Phi_{N}\right)+ \\
+H_{22}\left(f_{1}\right) \cos \left(2 \pi\left(f_{1}+\delta f_{1}\right)+\Phi_{1}\right)+\ldots+H_{22}\left(f_{N}\right) \cos \left(2 \pi\left(f_{N}+\delta f_{N}\right)+\Phi_{N}\right)
\end{gathered}
$$




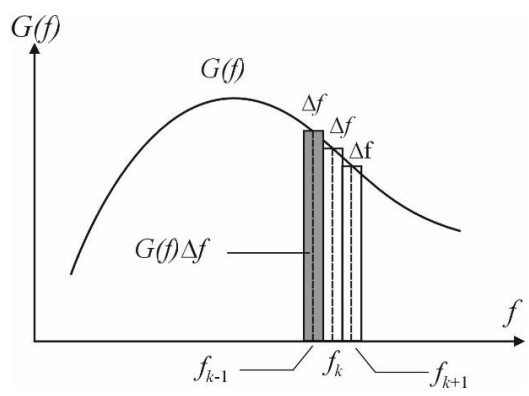

Fig. 1. Denotations in WAWS method

Cross-correlation of processes $p_{t}(t)$ and $p_{s}(t)$ can be written:

$$
R_{s t}(\tau)=\frac{1}{T} \int_{0}^{T} p_{s}(t) p_{t}(t+\tau) d t
$$

Assuming $\tau=0$, it will present as:

$$
R_{s t}(0)=\frac{1}{T} \int_{0}^{T} p_{s}(t) p_{t}(t) d t
$$

and for $k$-th component:

$$
\begin{gathered}
R_{s t}^{k}(0)=\frac{1}{T} \int_{0}^{T} p_{s}^{k}(t) p_{t}^{k}(t) d t= \\
=\frac{1}{T} \int_{0}^{T} \sum_{j=1}^{s} H_{s j}\left(f_{k}\right) \cos \left(2 \pi f_{k}^{\prime} t+\Phi_{k}\right) \sum_{j=1}^{t} H_{t j}\left(f_{k}\right) \cos \left(2 \pi f_{k}^{\prime} t+\Phi_{k}\right) d t= \\
=\frac{1}{T} \int_{0}^{T} \sum_{j=1}^{s} H_{s j}\left(f_{k}\right) \sum_{j=1}^{t} H_{t j}\left(f_{k}\right) \cos ^{2}\left(2 \pi f_{k}^{\prime} t+\Phi_{k}\right) d t=0.5 \sum_{j=1}^{s} H_{s j}\left(f_{k}\right) \sum_{j=1}^{t} H_{t j}\left(f_{k}\right)
\end{gathered}
$$

Because $H_{s j}\left(f_{k}\right)=H_{j s}\left(f_{k}\right)$ and $H_{t j}\left(f_{k}\right)=H_{j t}\left(f_{k}\right)$ it can be written that:

$$
R_{s t}^{k}(0)=\frac{1}{T} \int_{0}^{T} p_{s}^{k}(t) p_{t}^{k}(t) d t=0.5 \sum_{l=1}^{M} H_{s l}\left(f_{k}\right) H_{l t}\left(f_{k}\right)
$$


On the other hand:

$$
R_{s t}^{k}(\tau)=\int_{\Delta f_{k}} G_{s t}\left(f_{k}\right) \cos 2 \pi f_{k} \tau d f_{k}
$$

$$
R_{s t}^{k}(0)=\int_{\Delta f_{k}} G_{s t}\left(f_{k}\right) \cdot 1 d f_{k}
$$

Taking into account integration interval $\Delta f_{k}$ :

$$
R_{s t}^{k}(0)=G_{s t}\left(f_{k}\right) \Delta f_{k}
$$

and comparing Eqs. (2.14) and (2.17) it can be seen that:

$$
\sum_{l=1}^{M} H_{s l}\left(f_{k}\right) H_{l t}\left(f_{k}\right)=2 G_{s t}\left(f_{k}\right) \Delta f_{k}
$$

or in developed form:

$$
\left[\begin{array}{cccc}
H_{11}\left(f_{k}\right) & 0 & \cdots & 0 \\
H_{21}\left(f_{k}\right) & H_{22}\left(f_{k}\right) & \cdots & 0 \\
\vdots & \vdots & \ddots & \vdots \\
H_{M 1}\left(f_{k}\right) & H_{M 2}\left(f_{k}\right) & \cdots & H_{M M}\left(f_{k}\right)
\end{array}\right] \cdot\left[\begin{array}{cccc}
H_{11}\left(f_{k}\right) & H_{12}\left(f_{k}\right) & \cdots & H_{1 M}\left(f_{k}\right) \\
0 & H_{22}\left(f_{k}\right) & \cdots & H_{2 M}\left(f_{k}\right) \\
\vdots & \vdots & \ddots & \vdots \\
0 & 0 & \cdots & H_{M M}\left(f_{k}\right)
\end{array}\right]=\left[\begin{array}{c}
2 G_{s t}\left(f_{k}^{\prime}\right) \Delta f_{k} \\
2 G_{s t}\left(f_{k}^{\prime}\right) \Delta f_{k} \\
\vdots \\
2 G_{s t}\left(f_{k}^{\prime}\right) \Delta f_{k}
\end{array}\right]
$$

so:

$$
\mathbf{H}\left(f_{k}\right) \mathbf{H}\left(f_{k}\right)^{T}=2 \Delta f_{k} \mathbf{G}\left(f_{k}\right)
$$

Summing up, matrix $\mathbf{H}\left(f_{k}\right)$ can be obtained from the decomposition of cross-power spectral matrixes $2 \Delta f_{k} \mathbf{G}\left(f_{k}\right)$, which are connected with the frequency band between $f_{k}-\Delta f / 2$ and $f_{k}+\Delta f / 2$. Moreover, matrix element $\mathbf{G}\left(f_{k}\right)$ can be written: 


$$
G_{s t}\left(f_{k}\right)=\sqrt{G_{s}\left(f_{k}\right) G_{t}\left(f_{k}\right)} \cdot \operatorname{Coh}_{s t}\left(f_{k}\right)
$$

where: $G_{s}\left(f_{k}\right), G_{t}\left(f_{k}\right)$ - one sided PSD functions which refer to two points $s, t$; $\operatorname{Coh}_{s t}\left(f_{k}\right)$ - coherence function between these points.

The simulation procedure in the case of vortex excitation is much simpler. In connection with the full correlation of the vortex excitation process in domain $\Delta L$ of the structure, the simulation procedure is carried out only at one point $\left(z_{0}\right)$. According to this Eq. (2.2) can be replaced:

$$
p(t)=\sum_{k=1}^{N} H_{k} \cos \left(2 \pi f_{k}^{\prime} t+\Phi_{k}\right)
$$

Considering the correlation function for process $p(t)$ :

$$
R_{i}(\tau)=\frac{1}{T} \int_{0}^{T} p(t) p(t+\tau) d t
$$

for $k$-th component, and for $\tau=0$, it can be seen that:

$$
R_{i}^{k}(0)=\frac{1}{T} \int_{0}^{T} H_{k}^{2} \cos ^{2}\left(2 \pi f_{k}^{\prime} t+\Phi_{k}\right) d t
$$

Calculating the integral in Eq. (2.23) it is obtained:

$$
R_{i}^{k}(0)=H_{k}^{2} / 2
$$

On the other hand:

$$
R_{i}^{k}(\tau)=\int_{\Delta f_{k}} G_{i}\left(f_{k}\right) \cos \left(2 \pi f_{k} t+\Phi_{k}\right) d f_{k}
$$

Taking into account integral interval $\Delta f_{k}$ : 


$$
R_{i}^{k}(0)=G_{i}\left(f_{k}\right) \Delta f_{k}
$$

and comparing Eqs. (2.24) and (2.26) it is:

$$
H_{k}^{2} / 2=G_{i}\left(f_{k}\right) \Delta f_{k} \Rightarrow H_{k}=\sqrt{2 G_{i}\left(f_{k}\right) \Delta f_{k}}
$$

Considering the above, Eqs. (2.2) and (2.21) can be finally rewritten as:

$$
p(t)=\sum_{k=1}^{N} \sqrt{2 G_{i}\left(f_{k}\right) \Delta f_{k}} \cos \left(2 \pi f_{k}^{\prime} t+\Phi_{k}\right)
$$

The general algorithm of calculations according to WAWS can be outlined in the following steps:

a) Compilation of data about PSD function - frequency interval $\Delta f$, number of intervals $N_{f}$, and the form of results - the time step of the resulting calculation $\Delta t$, the number of time steps $N_{t}$.

b) Determination of matrixes $\mathbf{H}\left(f_{k}\right)$, consisting of:

- determination of PSD function $G_{i}\left(f_{k}\right)$ at points (single point),

- calculation of the coherence function $\operatorname{Coh}_{i j}\left(f_{k}\right)$ between points,

- determination of cross-PSD matrixes $\mathbf{G}\left(f_{k}\right)$ for particular frequencies,

- decomposition of matrixes $2 \Delta n \mathbf{G}\left(f_{k}\right)$ into triangle matrixes $\mathbf{H}\left(f_{k}\right)$.

In the case of vortex excitation, this step is much simpler, according to Eqs. (2.27)-(2.28).

c) Generation of $N$ random numbers: $\delta n_{k}$ and $\Phi_{k}$.

d) Determination of the stochastic process values in particular points (single point) at consecutive time steps according to Eqs. (2.1) or (2.28). Computations are based on the loops from 1 to $T$, in which values for particular points (single point) are calculated.

\subsection{AR - AUTO-REgRESSIVE}

The simulation equation of the process at a given point can be expressed in the following form:

$$
p(t)=\sum_{k=1}^{R} \psi_{k} p(t-k \Delta t)+N(t)
$$

where: $t$ - time, $\psi_{k}$ - auto-regression coefficients, $R$ - order of the method, $N(t)$ - stochastic process with a mean value equal to 0 . 
The value of the process at the given time step is calculated as a weighted average sum of $R$ steps of the process "backwards" and random value. There are $R$ unknown auto-regression coefficients $\psi_{1}$, $\psi_{2}, \ldots, \psi_{R}$ and an unknown value $N(t)$ in Eq. (2.29). These unknowns are determined on the basis of cross-correlation functions in the following way:

1. Eq. (2.29) is multiplied by the value of the process which was generated $s \Delta t$ before $t: p(t-s \Delta t)$ :

$$
p(t) p(t-s \Delta t)=\sum_{k=1}^{R} \Psi_{k} p(t-k \Delta t) p(t-s \Delta t)+\sigma_{N} N(t) p(t-s \Delta t)
$$

2. Both sides of equation are integrated in the time domain:

$$
\frac{1}{T} \int_{0}^{T} p(t) p(t-s \Delta t) d t==\sum_{k=1}^{R}\left[\frac{\Psi_{k}}{T} \int_{0}^{T} p(t-k \Delta t) p(t-s \Delta t) d t\right]+\frac{1}{T} \int_{0}^{T} N(t) p(t-s \Delta t) d t
$$

Expressions in the above equation can be replaced by correlation functions:

$$
\begin{gathered}
R^{p p}(-s \Delta t)=\frac{1}{T} \int_{0}^{T} p(t) p(t-s \Delta t) d t \\
R^{p p}((k-s) \Delta t)=\frac{1}{T} \int_{0}^{T} p(t-k \Delta t) p(t-s \Delta t) d t \\
R^{N p}(-s \Delta t)=\frac{1}{T} \int_{0}^{T} N(t) p(t-s \Delta t) d t
\end{gathered}
$$

Moreover, $R^{N p}(-s \Delta t)=0$ for $s \neq 0$, (meaning that: $\left.t_{1} \neq t_{2}\right)$, because processes $N(t)$ and $p(t)$ depend on each other only when $s=0$ (meaning that: $t_{1}=t_{2}$ ), and then $R^{N p}(-s \Delta t) \neq 0$.

Correlation functions can be calculated on the basis of PSD function due to the relationship:

$$
R^{p p}(\Delta t)=R^{p p}(-\Delta t)=\int_{0}^{+\infty} G_{i}(f) \cos (2 \pi f \Delta t) d f
$$

where: $G_{i}(f)$ - PSD function. 
3. Taking into account the relations mentioned above, the following equations are obtained:

$$
\begin{gathered}
R^{p p}(-s \Delta t)=\sum_{k=1}^{R} \Psi_{k} R^{p p}((k-s) \Delta t), \quad s=1 \ldots R \\
R^{p p}(0)=R^{N p}(0)+\sum_{k=1}^{R} \Psi_{k} R^{p p}(k \Delta t), \quad s=0
\end{gathered}
$$

The first of these relations is a system of equations with $R$ unknown coefficients $\psi_{k}$ and should be solved first. The system of equations in Eq. (2.36) can be written explicitly:

$$
\begin{cases}s=1 & R^{p p}(-1 \Delta t)=\Psi_{1} R^{p p}((1-1) \Delta t)+\ldots+\Psi_{k} R^{p p}((k-1) \Delta t) \\ s=2 & R^{p p}(-2 \Delta t)=\Psi_{1} R^{p p}((1-2) \Delta t)+\ldots+\Psi_{k} R^{p p}((k-2) \Delta t) \\ \vdots & \vdots \\ s=R=k & R^{p p}(-k \Delta t)=\Psi_{1} R^{p p}((1-k) \Delta t)+\ldots+\Psi_{k} R^{p p}((k-k) \Delta t)\end{cases}
$$

and, after further simplifications, in matrix notation:

$$
\left[\begin{array}{c}
R^{p p}(-1 \Delta t) \\
R^{p p}(-2 \Delta t) \\
\vdots \\
R^{p p}(-k \Delta t)
\end{array}\right]=\left[\begin{array}{cccc}
R^{p p}(0 \Delta t) & R^{p p}(1 \Delta t) & \ldots & R^{p p}((k-1) \Delta t) \\
R^{p p}(-1 \Delta t) & R^{p p}(0 \Delta t) & \ldots & R^{p p}((k-2) \Delta t) \\
\vdots & \vdots & \vdots & \vdots \\
R^{p p}((1-k) \Delta t) & R^{p p}((2-k) \Delta t) & \ldots & R^{p p}(0 \Delta t)
\end{array}\right] \cdot\left[\begin{array}{c}
\Psi_{1} \\
\Psi_{2} \\
\vdots \\
\Psi_{k}
\end{array}\right]
$$

Correlation functions for different values of $s \Delta t$ can therefore be determined on the basis of PSD functions, which leads to a system of linear equations with unknown values of $\psi k$.

Eq. (2.37) can be rewritten in the developed form:

$$
R^{p p}(0)=R^{N p}(0)+\Psi_{1} R^{p p}(1 \Delta t)+\Psi_{2} R^{p p}(2 \Delta t) \ldots+\Psi_{k} R^{p p}(k \Delta t)
$$

If values $\psi_{k}$ and $R^{p p}(0)$ are known, the correlation coefficient $R^{N p}(0)$ between $p(t)$ and $N(t)$, for $s=0$ can be calculated as: 


$$
R^{N p}(0)=R^{p p}(0)-\Psi_{1} R^{p p}(1 \Delta t)+\Psi_{2} R^{p p}(2 \Delta t) \ldots+\Psi_{k} R^{p p}(k \Delta t)
$$

The values of $N(t)$ at each time step $t$, are determined according to the equation:

$$
N(t)=\sqrt{R^{N p}(0)} \cdot \varepsilon(t)
$$

where $\varepsilon(t)$ - the uncorrelated stochastic process of the mean equal to 0 and variance equal to 1.0 . It should be emphasized that the initial values of the process in the simulation are white noise which is filtrated at next steps to the required process.

The general algorithm of calculations in the AR model can be described in the following steps:

a) Compilation of data about PSD function - frequency interval $\Delta f$, number of intervals $N_{f}$, and the form of the results - the time step of result calculation $\Delta t$, the number of time steps $N_{t}$. (much like in the WAWS algorithm).

b) Determination of PSD function $G_{i}\left(f_{k}\right)$.

c) Calculation of correlation coefficients in the systems of equations: $R^{p p}(s \Delta t)$.

d) Solution of the system of equations to calculate auto-regressive coefficients $\psi_{k}$.

e) Determination of $R^{N p}(0)$.

f) Determination of the stochastic process $p(t)$ in consecutive time steps. Computations are based on loops, from 1 to $T$, in which an uncorrelated random process $\varepsilon(t)$ is generated, and then $N(t)$ and finally $p(t)$ are calculated.

\section{RESULTS OF SIMULATIONS AND DISCUSSION}

A computer program, cooperating with FEM system, was created to implement own mathematical model of vortex excitation. The program allows for a simulation of crosswind loads caused by vortex excitation and the lateral response of the structure in real-time. A detailed description of the model can be found in [31-34]. This paper contains a short explanation of the mathematical model basis and its numerical implementation, which is described in the following 8-step procedure.

1. Geometrical and material data of the structure is used to build a discrete model. For slender structures of circular cross-sections, a beam model is accepted. Modal analysis of the structure is performed using the FEM program. Dynamic characteristics - frequencies and mode shapes are obtained as results (Fig. 2). 


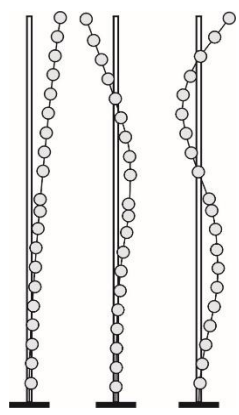

Fig. 2. Discrete model of tower-like structure. Three first mode shapes

2a. Flow parameters like: $I_{u}$ - turbulence intensity, $L_{u}$ - turbulence length scale, and $u(z)$ - vertical wind speed profile are determined. The equivalent, critical vortex excitation for the unsteady wind flow and laterally vibrating structure and PSD function of the process can be calculated:

a) critical vortex excitation:

$$
w_{y}(z, t)=\left.\left[q_{c} \cdot D \cdot\left(1+\alpha \cdot \sigma_{\hat{\eta}}\right)^{3} \cdot \hat{w}_{y}(z, t)\right]\right|_{z=z_{0}} \cdot Y(z)
$$

b) non-dimensional vortex excitation:

$$
\hat{w}_{y}(z, t)=\left.\left[\left[\frac{u_{m}(z, t)}{u_{c}}\right]^{2} C_{y}(z, t) \cdot \sin \left(2 \pi f_{i} t+\varphi\right)\right]\right|_{z=z_{0}}
$$

c) PSD function of non-dimensional vortex excitation:

$$
\frac{f \cdot G_{\hat{w}_{y}}(z, f)}{\sigma_{\hat{w}}^{2}}=\frac{k}{\sqrt{\pi} B} \frac{f}{f_{i}} \exp \left[-\left(\frac{1-f / f_{i}}{B}\right)^{2}\right]
$$

In the above equations: $z$-co-ordinate (height, span), $t$ - time, $q_{c}=0.5 \rho u_{c}{ }^{2}-$ pressure of the critical wind speed $u_{c}, D$ - characteristic cross-section diameter, $\alpha$-parameter describing the increase in the effective cross-section diameter (experimental value), $\sigma_{\hat{\eta}}$ - standard deviation of the structure's response under vortex excitation (given in non-dimensional displacements), $\left(1+\alpha \cdot \sigma_{\hat{\eta}}\right)^{3}$ - factor taking into account the increase in the effective cross-section diameter $D$ during vibrations, $Y(z)-$ 
deterministic function which describes the zone (zones) along the height (span) of structure $\Delta L$ where vortex excitation can appear, $z_{0}$ - central point of domain $\Delta L, C_{y}(\mathrm{z}, t)$ - aerodynamic coefficient which depends on the parameters of wind flow $\left(I_{u}\right.$ - turbulence intensity, $L_{u}$ - turbulence length scale, $\operatorname{Re}-$ Reynolds Number, $\alpha_{w}$ - mean angle of wind attack) and structure geometry ( $K-$ cross-section shape, $k_{L}$ - structure slenderness, $k_{B}$ - cross-section slenderness, $k_{s}$ - equivalent surface roughness), $f_{i}-i$-th frequency of natural vibrations, $\varphi$ - shift phase angle, $f$ - frequency, $\sigma_{\hat{w}}$ - standard deviation of the non-dimensional vortex excitation (experimental value), $k$ - factor, of value less than 1.0, which takes into account the participation of buffeting forces caused by atmospheric turbulence in the crosswind load (experimental value), $B$-non-dimensional bandwidth parameter (experimental value). There are four experimental parameters describing the semiempirical model of vortex excitation. In general, the values of these parameters are accepted on the basis of the procedures collected in [35]; they depend on several wind flow parameters $\left(I_{u}, L_{u}, \mathrm{Re}\right.$, $\left.\alpha_{w}\right)$ as well as structure geometry $\left(K, k_{L}, k_{B}, k_{s}\right)$.

2b. A physical description of the wind flow around the structure with regard to vortex excitation zones is performed. Several physical aspects of the flow around the circular cylinders are considered by functions $\Theta_{i}(z)$. It is assumed that vortex shedding is fully correlated along the structure in the domain described by function $\Gamma(z)$. Function $Y(z)$, zone (zones) $\Delta L$ where vortex excitation is possible, and the central point of $\Delta L-z_{0}$ are determined as the final results. The procedure of assuming $Y(z)$ for a cantilevered structure is shown in Fig. 3. A detailed description of all functions is presented in [31-34].

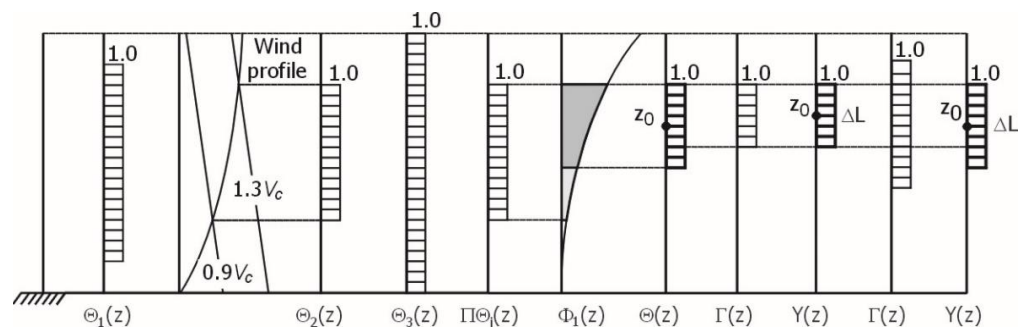

Fig. 3. The procedure of assuming $Y(z), \Delta L, z_{0}: \Theta_{1}(z)$ - function of disturbances caused by boundary zones (base and top) and significant changes in the cross-section; $\Theta_{2}(z)$ - function of influences of the mean and critical wind speed profiles; $\Theta_{3}(z)$ - function of the first mode shape $\Phi_{1}(z)$; $\Theta_{i}(z)$ - product of $\Theta_{i}(z) ; \Theta(z)$ function which considers the influence of the variations of vibration amplitude along the structure; $\Gamma(z)$ function connected with the normalised space correlation function of the equivalent vortex excitation which is fully correlated in domain $\Delta L ; Y(z)$ - product of $\Theta(z)$ and $\Gamma(z)$, giving the final domain $\Delta L$ and point $z_{0}$. 
3. The process of equivalent critical vortex excitation is generated in point $z_{0}$ (using WAWS or AR, on the basis of PSD function). Vortex excitation is fully correlated in the domain determined by $\Gamma(z)$, and therefore the time varying load can be accepted as a constant in domain $\Delta L$.

The first simulation of the crosswind load caused by vortex excitation is carried out in time domain $T_{0}$ under the assumption that: $\sigma_{\hat{\eta}}=0$.

There are two examples of load time histories generated through the use of the WAWS and AR in Fig. 4. The following descriptions are introduced: $\Delta f$ - frequency step, $N_{f}$ - number of spectrum parts, $\Delta t$ - time step, $N_{t}$ - number of time steps, $T_{0}=\Delta t N_{t}$ - time domain in which load is generated.

4. Checking the validity of load simulation, several processes of the load are generated within the same parameters, then FFT is applied, and, next, PSD functions are determined. The results are averaged and compared with the assumed PSD. Different parameters of simulation were applied in several cases, and according to the analysis of these results the choice of the optimal method was possible. It is shown that AR cannot be used for vortex excitation simulation, as the resultant spectrum differs significantly from the target spectrum. The consistency between the averaged and assumed values is satisfactory enough in the case of WAWS, however. This method was accepted in further calculations. Verification of both methods for different parameters is presented in Fig. 5.

a)

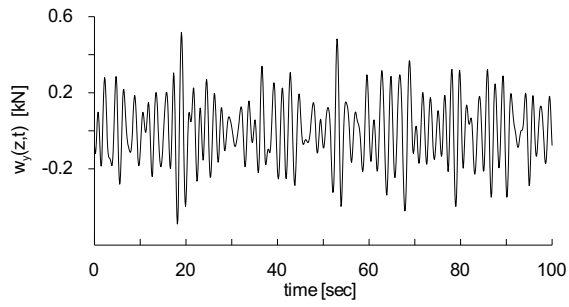

c)

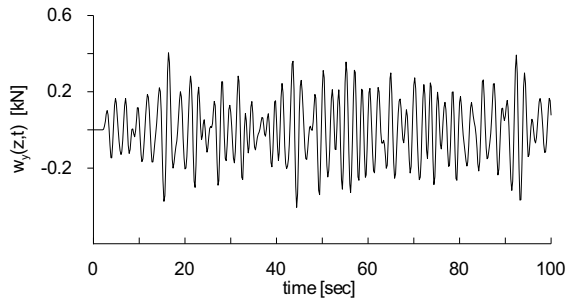

b)

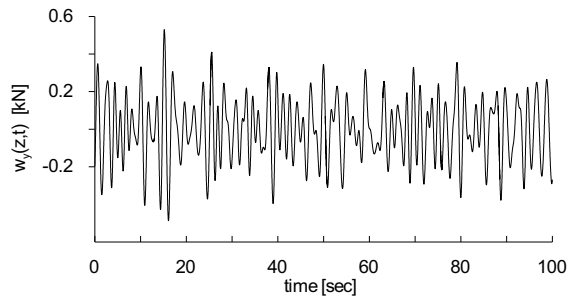

d)

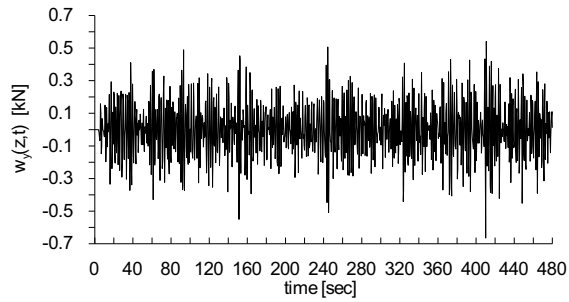

Fig. 4. Examples of time-dependent load $w_{y}(z, t)$, simulated with WAWS, for $\sigma_{\hat{\eta}}=0$ : a) $N_{t}=1000, \Delta t=$ $\left.0.1 \mathrm{~s}, N_{f}=500, \Delta f=0.01 \mathrm{~Hz}, T_{0}=100 \mathrm{~s}, \mathrm{~b}\right) N_{t}=10000, \Delta t=0.01 \mathrm{~s}, N_{f}=600, \Delta f=0.01 \mathrm{~Hz}, T_{0}=100 \mathrm{~s}$; simulated with AR, for $\sigma_{\hat{\eta}}=0$ : c) $N_{t}=500, \Delta t=0.2 \mathrm{~s}, N_{f}=600, \Delta f=0.01 \mathrm{~Hz}, T_{0}=100 \mathrm{~s}$, d) $N_{t}=1200, \Delta t=$ $0.4 \mathrm{~s}, N_{f}=2000, \Delta f=0.002 \mathrm{~Hz}, T_{0}=480 \mathrm{~s}$. The order of AR is 10 
a)

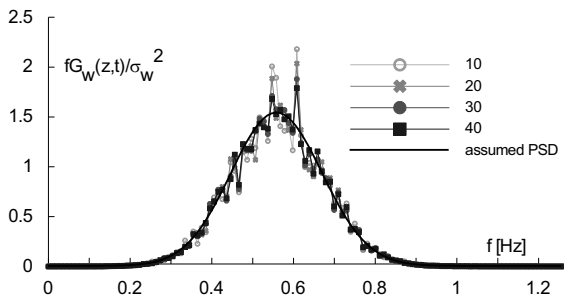

c)

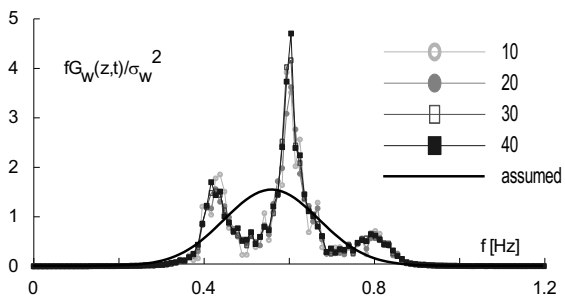

b)

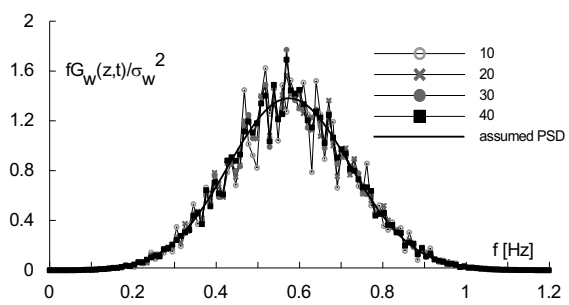

d)

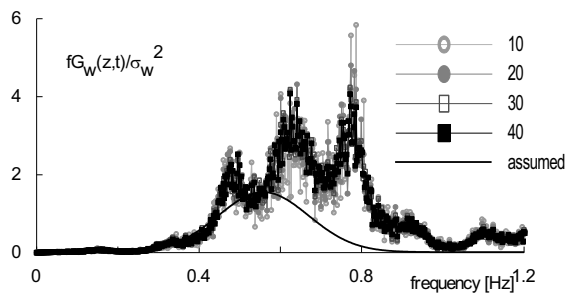

Fig. 5. Comparison between average and assumed PSD functions. Simulation with WAWS $(a, b)$ and AR (c,d). 10, 20, 30, 40 processes averaged. Simulation parameters as in Fig. 4

5. The load generated in point $z_{0}$ is applied in the FEM system to the structure in domain $\Delta L$ at each time step $\Delta t$, in time $T_{0}$. Direct integration is used to solve the system of motion equations. The time history of displacements in time $T_{0}$ at each time step $\Delta t$ is obtained (Fig. 6).
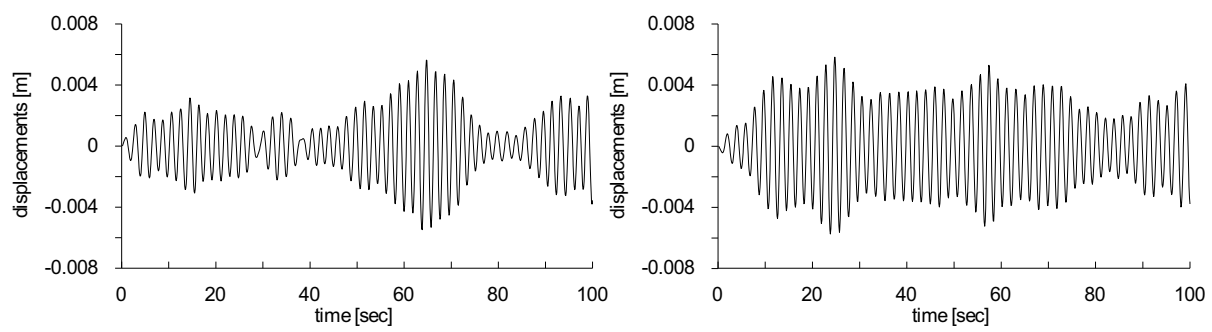

Fig. 6. Examples of time histories of displacements in point $\mathrm{z}_{0}$ in time $\Delta t, \sigma_{\hat{\eta}}=0, N_{t}=1000, \Delta t=0.1 \mathrm{~s}$

6. A new value of the standard deviation of displacements $\sigma_{\hat{\eta}}$ is calculated on the basis of a short time interval of time history of displacements $\chi_{1} T_{1}$, where $T_{1}$ - the first period of natural vibrations of the analysed structure; $\chi_{1}-$ a parameter of a value greater than 1 . The low value of $\chi_{1}$ allows taking into account feedback between vibrations and vortex shedding, while at the high value of $\chi_{1}$ feedback is neglected. 
The values of $Y(z), \Delta L, z_{0}$ and also Eqs. (3.1)-(3.3) are actualised, and then, on the basis of the new $\sigma_{\hat{\eta}}$, the next time steps of the load in time domain $\left(T_{0}, T_{0}+\Delta \tau\right)$ are generated. The actualized load is applied to the structure in the FEM system.

7. The above steps $(5,6)$ are repeated. At each step of the calculations the interval $\chi_{1} T_{1}$ used for calculations of $\sigma_{\hat{\eta}}$ is shifted according to the time interval of the new generated load. The whole procedure is repeated $M$ times and load time histories as well as displacement are obtained in time $T$ (for $\sigma_{\hat{\eta}} \neq 0$ ), so it can then be stated that simulation is performed in real time. On the basis of displacements "backwards" the "forward" time steps of the load are generated.

There are some examples of variations of $\sigma_{\hat{\eta}}$ at each step of calculations, for different values of $\chi_{1} T_{1}$ in Fig. 7. As it can be seen, changes of $\sigma_{\hat{\eta}}$ are weak for higher intervals of $\chi_{1} T_{1}$ (Fig. 7a) and strong for lower intervals (Fig. 7b,c,d).

a)

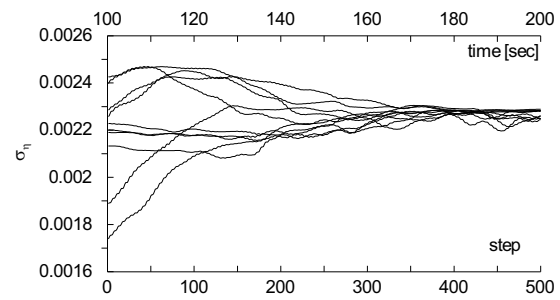

c)

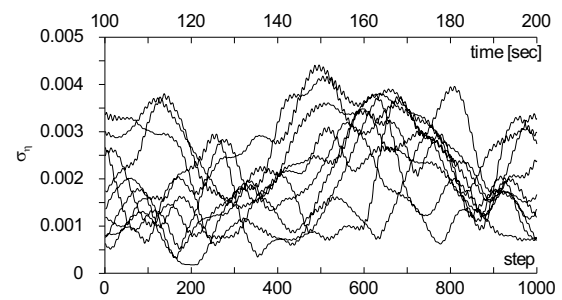

b)

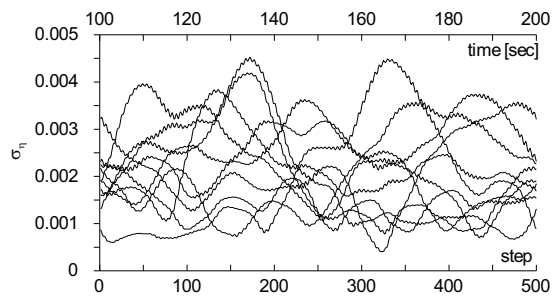

d)

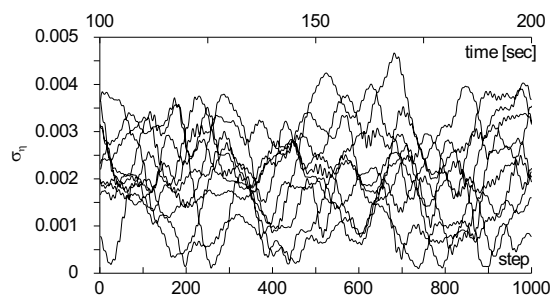

Fig. 7. $\sigma_{\hat{\eta}}$ for 10 processes, $N_{t}=1000, \Delta t=0.1 \mathrm{~s}$, a) $\chi=49, \Delta \tau=2 \Delta t$, repeated 500 times, b) $\chi=5$, $\Delta \tau=2 \Delta t$, repeated 500 times, c) $\chi=3, \Delta \tau=\Delta t$, repeated 1000 times, d) $\chi=1, \Delta \tau=\Delta t$, repeated 1000 times

8. It is necessary to repeat the whole procedure (stages 2-7) $N$ times to obtain valuable (averaged) results for stochastic processes. For analysis of the lateral response of the structure, the averaged maximum lateral top displacement (in the case of vertical structures) or any other point, in time $T$, from $N$ processes can be used: 


$$
\eta_{t o p}^{\max }=\frac{1}{N} \sum_{j=1}^{n} \eta_{j, t o p}^{\max }
$$

where: $\eta_{j, t o p}^{\max }=\max \left\{\eta_{j, i, t o p}\right\}, j-$ index of the process, $j=1,2, \ldots N, i$ - index of predicted discrete values at time $t_{i}=i \Delta t$ in time domain $T, i=1,2, \ldots, M, \eta_{j, i, t o p}=\eta_{j}\left(t_{i}\right)$ - discrete values of displacements of the $j$-th process in time $t_{i}$.

The presented procedure was used in calculations of several cantilevered structures (steel and concrete chimneys, concrete towers). Results concerning maximum lateral top displacement are in agreement with the full-scale data at hand. A detailed comparison of the computation results obtained according to the model and the full-scale results collected from the literature was presented in $[32,35]$.

\section{Conclusions}

Two methods of stochastic processes simulation were used for the direct generation of vortex excitation and the following final conclusions can be formulated.

The WAWS method can be used in a direct simulation of vortex excitation. The averaged PSD determined on the basis of the simulated processes gives good consistency with the assumed PSD (Fig. 5). The simulation procedure is very simple as the full correlation of the vortex excitation process is assumed and load generation is performed solely at one point.

The AR method cannot be used in a direct simulation of vortex excitation. It is probably caused by the long time steps $(\Delta t)$ which should be used in the simulation procedure according to this method. The values of $\Delta t$ equal to 0.2 or 0.4 , as in Fig. 5, do not give consistency between averaged and assumed PSD functions. The decrease of $\Delta t$ does not improve the results and the simulation loses stability while the increase of $\Delta t$ makes the AR method less suitable.

Methods used mostly for wind speed field simulation here were proven effective (WAWS) in a direct simulation of crosswind loads. 


\section{REFERENCES}

1 M. Shinozuka, C.M. Jan, "Digital simulation of random processes and its application", Journal of Sound and Vibrations 25(1): 111-128, (1972).

2. M. Shinozuka, "Stochastic mechanics", vol. I., Columbia University, New York, 1987.

3. C. Borri, F. Crocchini, L. Facchini, P. Spinelli, "Numerical simulation of stationary and non-stationary stochastic processes: a comparative analysis for turbulent wind fields", Proc. $9^{\text {th }}$ International Conference on Wind Engineering, "Retrospect and Prospect", vol. 1, New Delhi, 47-55, 1995.

4. C. Borri, "Generation procedures of stationary random processes simulating wind time series", Sezione Strutture 11, University of Florence, Italy, 1988.

5. A. Flaga, E. Błazik-Borowa, J. Podgórski, "Aerodynamics of slender structures and bar-cable structures", Monograph, Lublin Technical University, 2004 (in Polish).

6. A. Iannuzzi, P. Spinelli, “Artificial wind generation and structural response”, Journal of Structural Engineering 113(12): 2382-2398, 1987.

7. P. Spinelli, "The generation of wind histories for time domain analysis of structural response to wind action", Sezione Strutture 4, University of Florence, Italy, 1986.

8. M. Di Paola, I. Gullo, "Digital generation of multivariate wind field processes", Probabilistic Engineering Mechanics 16: 1-10, 2001.

9. A. Kareem, "Numerical simulation of wind effects: A probabilistic perspective", Journal of Wind Engineering and Industrial Aerodynamics 96: 1472-1497, 2008.

10. F. Ubertini, F. Giuliano, "Computer simulation of stochastic wind velocity fields for structural response analysis: comparisons and applications”, Advances in Civil Engineering, ID 749578, 2010.

11. J. Li, X. Wang, "An exponential model for fast simulation of multivariate non-Gaussian processes with application to structural wind engineering”, Probabilistic Engineering Mechanics 30: 37-47, 2012.

12. J. Li, L. Li, X. Wang, "A combined polynomial transformation and proper orthogonal decomposition approach for generation of non-Gaussian wind loads on large roof structures", Engineering Structures 102: 322-343, 2015.

13. L. Carassale, G. Solari, "Monte Carlo simulation of wind velocity fields on complex structures", Journal of Wind Engineering and Industrial Aerodynamics 94: 323-339, 2006.

14. M. Ciampoli, F. Petrini, G. Augusti, "Performance-Based Wind Engineering: Towards a general procedure", Structural Safety 33: 367-378, 2011.

15. V. Sepe, P. D'Asdia, "Influence of low-frequency wind speed fluctuations on the aeroelastic stability of suspension bridges", Journal of Wind Engineering and Industrial Aerodynamics 91 1285-1297, 2003.

16. W. Chunming, M. Bin, S. Tingting, "Research on the wind-induced vibration coefficient of transmission tower-line system", Physics Procedia 24: 149-154, 2012.

17. T. Wang, W. Han, F. Yang, W. Kong, "Wind-vehicle-bridge coupled vibration analysis based on random traffic flow simulation", Journal of Traffic and Transportation Engineering 1(4): 293-308, 2014.

18. M. Tomko, S. Kmet, R. Soltys, "Vibrations of an aramid anchor cable subjected to turbulent wind", Advances in Engineering Software 72: 39-56, 2014.

19. Y. Li, H. Liao, S. Qiang, "Simplifying the simulation of stochastic wind velocity fields for long cable-stayed bridges", Computers and Structures 82: 1591-1598, 2004.

20. F. Cluni, V. Gusella, F. Ubertini, "A parametric investigation of wind-induced cable fatigue", Engineering Structures 29: 3094-3105, 2007.

21. K. Aas-Jakobsen, E. Strømmen, "Time domain buffeting response calculations of slender structures", Journal of Wind Engineering and Industrial Aerodynamics 89: 341-364, 2001.

22. A. Flaga, J. Bęc, T. Lipecki, "Dynamic wind analysis of the cable-stayed bridge in Wrocław", [in] Recent Advances in Research on Environmental Effects on Buildings and People (Flaga A., Lipecki T. eds), Monograph, PAWE, pp. 119-130, 2010.

23. T. Lipecki, J. Bęc, G. Bosak, A. Flaga, "Aerodynamic analysis of a sinusoidal footbridge for pedestrian and bicycle traffic", Roads and Bridges 12(3): 297-316, 2013.

24. J. Bęc, T. Lipecki, A. Flaga, G. Bosak, "Model investigations and numerical analysis of an arch shaped footbridge", Roads and Bridges 12(4): 339-360, 2013.

25. J. Maeda, M. Makino, "Characteristics of gusty winds simulated by an ARMA model", Journal of Wind Engineering and Industrial Aerodynamics 41-44: 427-436, 1992.

26. E. Samaras, M. Shinozuka, A. Tsurui, "ARMA representation of random processes", ASCE Journal of Engineering Mechanics 111(3): 449-461, 1985. 
27. N.N. Minh, T. Miyata, H. Yamada, Y. Sanada, "Numerical simulation of wind turbulence and buffeting analysis of long-span bridges", Journal of Wind Engineering and Industrial Aerodynamics 83: 301-315, 1999.

28. M.T. Chay, F. Albermani, R. Wilson, "Numerical and analytical simulation of downburst wind loads", Engineering Structures 28: 240-254, 2006.

29. M.T. Chay, R. Wilson, F. Albermani, "Gust occurrence in simulated non-stationary winds", Journal of Wind Engineering and Industrial Aerodynamics 96: 2161-2172, 2008.

30. H. Zhang, L. Liu, M. Dong, H. Sun, "Analysis of wind-induced vibration of fluid-structure interaction system for isolated aqueduct bridge", Engineering Structures 46: 28-37, 2013.

31. A. Flaga, "Wind vortex-induced excitation and vibration of slender structures. Single structure of circular cross-section normal to flow", Monograph 202, Cracow, Poland, 1996.

32. A. Flaga, T. Lipecki, "Code approaches to vortex shedding and own model", Engineering Structures 32: $1530-1536,2010$.

33. T. Lipecki, A. Flaga, "Vortex excitation model. Part I. Mathematical description and numerical implementation", Wind \& Structures 16(5): 457-476, 2013.

34. T. Lipecki, A. Flaga, "Vortex excitation model. Part II. Application to real structures and validation", Wind \& Structures 16(5): 477-490, 2013.

35. ESDU 85038. Circular-cylindrical structures: dynamic response to vortex shedding. Part I: calculation procedures and derivation, London, ESDU Int. Ltd, 1990.

\section{LIST OF FIGURES:}

Fig. 1. Denotations in WAWS method

Rys. 1. Oznaczenia w metodzie WAWS

Fig. 2. Discrete model of tower-like structure. Three first mode shapes

Rys. 2. Model dyskretny konstrukcji wieżowej. Trzy pierwsze postaci drgań

Fig. 3. Procedure of assuming $Y(z), \Delta L, z_{0}$

Rys. 3. Procedura przyjęcia $Y(z), \Delta L, z_{0}$

Fig. 4. Examples of time-dependent load $w_{y}(z, t)$

Rys. 4. Przykłady zmian czasowych obciążenia $w_{y}(z, t)$

Fig. 5. Comparison between average and assumed PSD functions

Rys. 5. Porównanie uśrednionej i założonej funkcji gęstości widmowej mocy

Fig. 6. Examples of time histories of displacements in point $\mathrm{z}_{0}$ in time $\Delta t$

Rys. 6. Przykłady zmian czasowych przemieszczeń w punkcie $\mathrm{z}_{0} \mathrm{w}$ czasie $\Delta t$

Fig. 7. $\sigma_{\hat{\eta}}$ for 10 processes

Rys. 7. $\sigma_{\hat{\eta}}$ dla 10 procesów 


\title{
Zastosowanie Metod Symulacji Procesów Losowych do Wzbudzenia Wirowego
}

\author{
Słowa kluczowe: wzbudzenie wirowe, WAWS, AR, symulacja procesów stochastycznych, przekrój kołowy
}

\section{STRESZCZENIE:}

W pracy przedstawiono opis bezpośredniej symulacji obciążenia poprzecznego wiatrem powodowanego wzbudzeniem wirowym oraz odpowiedzi konstrukcji na to obciążenie. Analizowano konstrukcje wieżowe o kołowym przekroju poprzecznym (kominy stalowe, żelbetowe, wieże stalowe). Wyjaśniono podstawowe założenia modelu matematycznego obciążenia i jego implementacji numerycznej. W tym celu stworzono własny program komputerowy oparty na współpracy z komercyjnym systemem metody elementów skończonych, pozwalający na symulację obciążenia poprzecznego wzbudzeniem wirowym i odpowiedzi konstrukcji w czasie rzeczywistym. Na każdym kroku czasowym obliczeń, obciążenie poprzeczne jest generowane na podstawie informacji o przemieszczeniach konstrukcji uzyskanych z kroków poprzednich. W pracy pominięto dokładny opis modelu matematycznego i jego numerycznej implementacji, skupiając się na metodach symulacji. Wzbudzenie wirowe jest procesem losowym o charakterze wąsko lub szeroko pasmowym. Tak więc, do jego symulacji można wykorzystywać metody symulacji procesów losowych. W pracy rozpatrzono dwie: WAWS (weighted amplitude wave superposition) i AR (auto-regressive).

Obie metody służą w inżynierii wiatrowej głównie do symulacji stochastycznego pola prędkości wiatru w trzech kierunkach i w wielu punktach przestrzeni. W pracy podano przykłady ostatnich zastosowań WAWS i AR w inżynierii wiatrowej i aerodynamice budowli. Opisano obie metody, upraszczając ich równania do symulacji w jednym punkcie. Jest ona możliwa dzięki założeniu pełnej korelacji wzbudzenia wirowego w pewnym obszarze konstrukcji (co pozwala na przeprowadzenie symulacji tylko w jednym punkcie charakterystycznym). W pracy przedstawiono również podstawy teoretyczne modelu matematycznego wzbudzenia wirowego, podając główne równania nim rządzące oraz opis deterministyczny obszaru konstrukcji, w którym wzbudzenie wirowe może wystąpić.

W wyniku obliczeń i analiz przeprowadzonych na kominach stalowych i żelbetowych oraz wieżach żelbetowych stwierdzono, że metodę WAWS można wykorzystać w celu bezpośredniej symulacji wzbudzenia wirowego, zaś metody AR nie można. Weryfikacja symulacji polegała na porównaniu założonej funkcji gęstości widmowej mocy obciążenia i uśrednionej w wyniku symulacji kilkudziesięciu procesów o tych samych parametrach. Walidacja całości modelu została przeprowadzona za pomocą porównania przemieszczeń poprzecznych wierzchołków kominów ze zgromadzonymi z literatury wynikami pomiarów w skali rzeczywistej. 